$06 ; 11 ; 12$

\title{
Увеличение эффективности органических солнечных элементов с помощью просветляющих покрытий на основе фторидных композиций
}

\author{
(C) С.Х. Сулейманов ${ }^{1}$, P. Berger ${ }^{2}$, В.Г. Дыскин ${ }^{1, \uparrow}$, М.У. Джанклич ${ }^{1}$, \\ Н.А. Кулагина ${ }^{1}$, M. Kim ${ }^{2}$ \\ ${ }^{1}$ Институт материаловедения НПО „Физика-Солнце“ АН Узбекистана, \\ Ташкент, Узбекистан \\ ${ }^{2}$ The Ohio State University, Columbus, Ohio, USA \\ 『 E-mail: dyskin@uzsci.net
}

Поступило в Редакцию 2 февраля 2017 г.

Приведены результаты измерений вольт-амперных характеристик органических солнечных элементов как без, так и с антиотражающими покрытиями, материалы которых получены плавлением на солнечной печи смеси фторидов $\mathrm{MgF}_{2}$ и $\mathrm{CaF}_{2}$ двух концентраций 95:5 и 55:45 (wt.\%). Относительное увеличение коэффициента полезного действия органических солнечных элементов в первом случае составило $3.2 \%$, а во втором $-3.3 \%$.

DOI: 10.21883/PJTF.2018.07.45884.16730

Благодаря низкой стоимости и простой технологии производства органические солнечные элементы (ОСЭ) могут стать реальной альтернативой как планарным, так и каскадным солнечным элементам на основе кремния и других полупроводниковых материалов [1-4]. Лучшие лабораторные образцы ОСЭ имеют эффективность $\sim 13.2 \%$, что пока меньше, чем у кремниевых солнечных элементов, выпускаемых промышленно. Если удастся повысить эффективность ОСЭ, нанесенных только на стеклянные подложки, то это будет значительным достижением солнечной энергетики, поскольку гораздо экономичнее производить ОСЭ на больших (до $5 \mathrm{~m}^{2}$ ) стеклянных листах, чем на панелях той же площади, собранных из кремниевых солнечных элементов. Для успешной коммерциализации ОСЭ необходимо увеличить эффективность и время их эксплуатации. Увеличить поток солнечного 


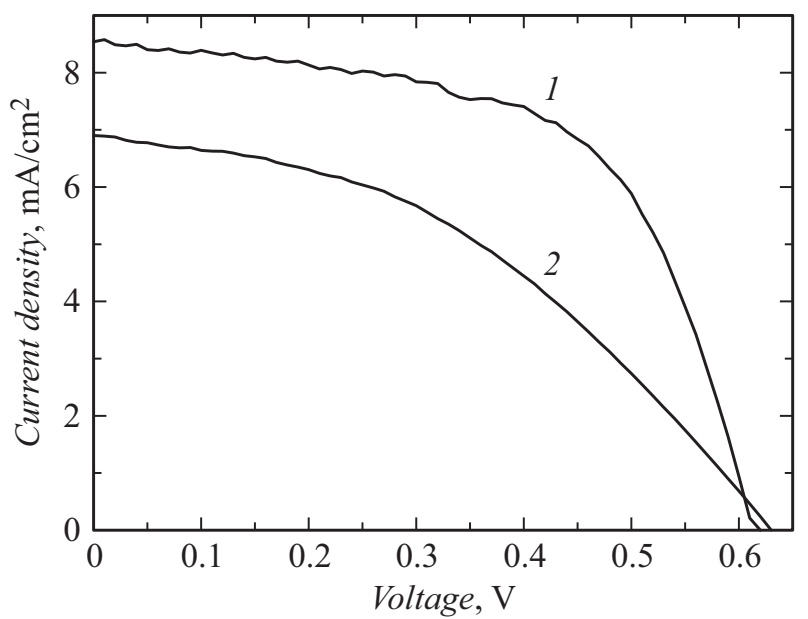

Рис. 1. Вольт-амперные характеристики ОСЭ, нанесенных при температурах подложки, равных 23 (1) и $30^{\circ} \mathrm{C}(2)$.

излучения через стекло и тем самым повысить коэффициент полезного действия фотоэлектрических батарей можно нанесением на стекло антиотражающего покрытия (АП). Так, в [5,6] эффект просветления стеклянных пластинок (чистых и с пленкой ITO) был получен с помощью АП, материал которого был синтезирован в солнечной печи плавлением смеси фторидов. Показано, что за счет нанесения АП коэффициент полезного действия увеличился на $2.0-3.0 \%$.

Цель настоящей работы - изучить влияние АП на эффективность ОСЭ с объемным гетеропереходом. Для экспериментов были выбраны стеклянные пластинки - как чистые, так и с пленкой ITO [7]. Для выбора оптимальной температуры на подложки с разной температурой были нанесены ОСЭ и на многопараметрическом анализаторе Keithley 4200 были измерены их вольт-амперные характеристики [8,9]. Оказалось (рис. 1), что уменьшение температуры нанесения активного слоя с 30 до $23^{\circ} \mathrm{C}$ ведет к увеличению эффективности с 1.81 до 3.06\%. Так как АП наносятся при более высоких температурах, было решено сначала наносить АП, а затем формировать слои ОСЭ. Материалом для АП служили проплавленные на солнечной печи смеси фторидов $\mathrm{MgF}_{2}$ и 

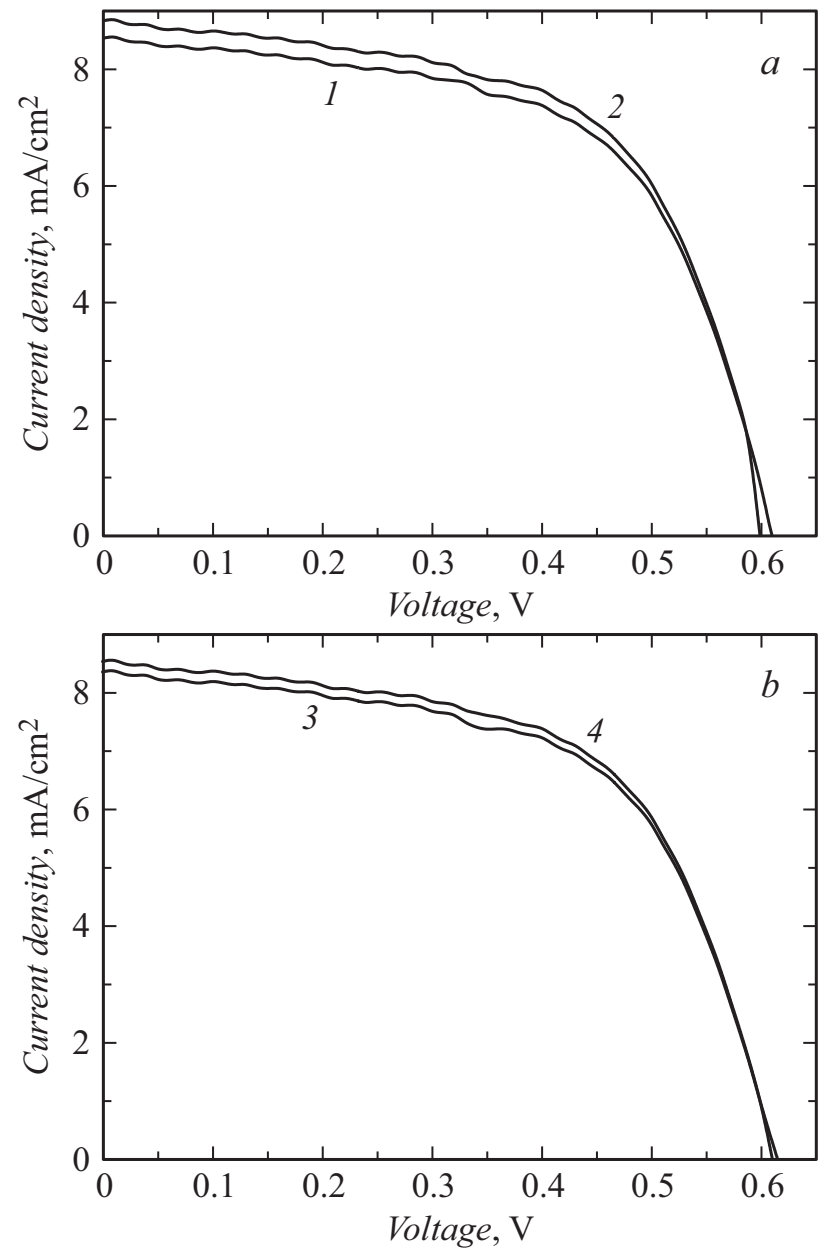

Рис. 2. Вольт-амперные характеристики ОСЭ на стеклянной подложке без антиотражающего покрытия $(1,3)$ и с антиотражающим покрытием $(2,4)$. Покрытия: $a-\mathrm{MC} 554, b-\mathrm{MC} 955$.

$\mathrm{CaF}_{2}$ двух концентраций (wt.\%): 95:5 (MC955) и 55:45 (MC554) [5,6]. Покрытия наносились с помощью вакуумного термического испарения

4 Письма в ЖТФ, 2018, том 44, вып. 7 
Приращение КПД за счет нанесения АП

\begin{tabular}{c|c|c}
\hline Номер кривой & $P_{\max }, \mathrm{mW} / \mathrm{cm}^{2}$ & $\Delta \eta, \%$ \\
\hline 1 (ОСЭ без АП) & 3.10 & \\
2 (с АП МС554) & 3.20 & 3.2 \\
3 (ОСЭ без АП) & 3.00 & 3.3 \\
4 (с АП МС955) & 3.10 &
\end{tabular}

на установке УВН-71П-3. Затем в одном цикле на стеклянные пластинки с пленкой ITO и АП наносились слои PEDOT:PSS, Р3НT:PCBM, $\mathrm{Ca}, \mathrm{Al}[5]$. Результаты измерений вольт-амперных характеристик ОСЭ представлены на рис. 2. По измеренным кривым вольт-амперных характеристик определялась максимальная мощность полученных ОСЭ, и оценивался эффект просветления по формуле

$$
\Delta \eta=\frac{P_{1}}{P_{0}}-1,
$$

где $\Delta \eta$ - относительное изменение КПД, $P_{0}-$ максимальная мощность ОСЭ без АП, $P_{1}$ - максимальная мощность ОСЭ с АП. Результаты измерений максимальной мощности и расчета $\Delta \eta$ занесены в таблицу. Из таблицы следует, что за счет эффекта просветления стеклянных подложек с нанесенными АП составов МС955 и МС554 коэффициент полезного действия ОСЭ увеличился на 3.3 и $3.2 \%$.

На основании полученных результатов можно сделать вывод, что исследованные нанокомпозиционные покрытия являются антиотражающими, повышают эффективность и могут быть рекомендованы для использования в качестве однослойных просветляющих покрытий для ОСЭ.

Следует отметить, что поиск оптимального состава материала антиотражающего покрытия и оптимальной технологии нанесения ОСЭ требует дальнейших исследований.

Работа выполнена при поддержке американского фонда CRDF Global в рамках проекта N M/CRDF-37/2013.

Письма в ЖТФ, 2018, том 44, вып. 7 


\section{Список литературы}

[1] Krebs F.C. // Solar Energy Mater. Solar Cells. 2009. V. 93. P. 394-412.

[2] Трошин П.А., Любовская Р.Н., Разумов В.Ф. // Рос. нанотехнологии. 2008. T. 3. № 5-6. C. 56-77.

[3] Ихсанов Р.Ш., Проценко И.Е., Усков А.В. // Письма в ЖТФ. 2013. Т. 39. B. 10. C. $1-8$.

[4] Миличко В.А., Шалин А.С., Мухин И.С., Ковров А.Э., Красилин А.А., Виноградов А.В., Белов П.А., Симовский К.Р. // УФН. 2016. Т. 186. № 8. C. $801-852$.

[5] Сулейманов С.Х., Berger Р., Дыскин В.Г., Джсанклич М.У., Бугаков А.Г., Дудко О.А., Кулагина Н.А., Кіт М. // Письма в ЖТФ. 2016. Т. 42. В. 7. C. $47-52$.

[6] Сулейманов С.Х., Berger Р., Дыскин В.С., Джсанклич М.У., Кулагина Н.А., Kim M. // Гелиотехника. 2016. № 2. С. 71-72.

[7] www.delta-technologies.com

[8] Yoon W.J., Jung K.Y., Liu J., Duraisamy T., Revur R., Teixeira F.L., Sengupta S., Berger P.R. // Solar Energy Mater. Solar Cells. 2010. V. 94. P. 128-132.

[9] www.tehencom.com

$4^{*}$ Письма в ЖТФ, 2018, том 44, вып. 7 